\author{
Ana Gnjatović* \\ University of Priština \\ Faculty of Arts, Kosovska Mitrovica
}

\title{
THE HOUSE THAT IS HERE BUT IS NOT THAT: ON THE LONESOME SKYSCRAPER BY IVANA OGNJANOVIĆ
}

\begin{abstract}
This paper interprets the piece Lonesome Skyscraper for orchestra and electronics (2012) by Ivana Ognjanović, relying on the theoretical essay about the composition given by the author herself. Inspired by the fate of the tallest residential building in Pécs, which was evacuated because of a construction error and left abandoned and isolated for almost 30 years, I. Ognjanović creates an organic sound unity by connecting various ambient (field recordings) and concrete sounds in the electronic part with responses coming from the orchestral part. Using the time stretching technique, suspending the melodic component, and avoiding the formal and motivic development, the author builds her own version of the skyscraper, an acoustic space through which the memory of the sonic environment is howling.
\end{abstract}

Keywords: Ivana Ognjanović, Lonesome Skyscraper, sonic environment, acoustic space, time stretching, electroacoustic music, orchestra music

* Author contact information: anagnjatovic@gmail.com 
Composition Lonesome Skyscraper for symphony orchestra and electronics was written in 2012, and was first performed in Belgrade in February, 2019 by the Symphonic Orchestra of Radio Television Serbia as a part of the concert series "Premieres". The Italian conductor Jacopo Sipari di Pescasseroli (1985) conducted the Symphonic Orchestra, while the composer herself played the electronic part.

As the author said about this piece, "It was inspired by the unusual fate of an unoccupied skyscraper that is located in Pecs, in Hungary". "The high-rise of Pécs (Pécsi Magasház), ${ }^{2} 25$ storeys high, was built during the 1970s. This megalomanic modernist concrete structure had more than 800 residents. After several years, the first signs were noticed of critical damage to the inner structure of the building. Eventually, it was concluded that the building was unsafe for habitation and in 1989, the building was definitively evacuated. Subsequently, for almost three decades, all the plans for repairs, repurposing and demolition turned out to be too expensive or unfeasible. The unstable structure stood for all that time like an empty shell, an oversized playground for the wind and pigeons.

In 2010, as a member of the electronic music ensemble EBE (European Bridges Ensemble, a multimedia ensemble specialising in composition and performance via the Internet), Ivana Ognjanović visited the town of Pécs, the European Capital of Culture at the time. It was then that she started working on the piece and making field recordings which she later used in the composition Lonesome Skyscraper.

The authenticity of the recordings was, however, not in the author's focus.

This time I recorded everything I thought might help me depict this unusual building, by combining edited sounds into a logical musical sequence, with an awareness of what could be done with the sounds later in the mix. [...] Sounds were recorded on the ground floor of the skyscraper, in front of it, and in quite different spaces as well. Once recorded, I later cut the sounds, shortened them, neutralising the noise wherever it was possible... ${ }^{3}$

1 Quotes are taken form the author's autopoetical/analytical text about the piece: Ivana Ognjanović, Lonesome Skyscraper za simfonijski orkestar i elektroniku - prevod elektronskog zvuka u akustični [Lonesome Skyscraper for symphony orchestra and electronics - translation of electronic sound into acoustic], manuscript, Belgrade, October 2012.

2 https://en.wikipedia.org/wiki/High-rise_of_Pécs

3 I. Ognjanović, op. cit., 3. 
Often, besides being a necessary procedure dictated by the aesthetic and technical requirements of the process of creating the electronic part, the neutralisation of background noise can, in this case, also be understood as a metaphorical act. The removal of what fills the building in the moment of recording (such as the wind whistling through the concrete skeleton) while adding elements that bring it closer to what it no longer is (preverbal human voices, traces of incomprehensible conversations, the echoes of sounds from everyday life and things people use), is one of the methods by which the composer builds an interspace which is at the same time elegiac and unsettling - between what it once was and what it is now. Her musical imagination lives neither in that lively environment before the first cracks, nor in the senselessness of a building-monument. It is concentrated on a sad structure that one defines by what (or who) is missing, on the awareness that it is abandoned, unnaturally emptied, lonely.

The first sound information we get from the score is a record of space. There is a description of the sound in the electronic part: ambient noise (sempre). This humming was created by stretching the sound materials of a recorded conversation that was conducted in the ground floor of the skyscraper. Although drastically stretched in time, in its structure one can occasionally recognise the slow melody of speech, the contours of original sonority. Time stretching allows the listener to hear the inner quality of sound, by augmenting its gestures and stripping bare its spectrum. Elongated duration allows the sound of a somewhat recognisable source to reverberate within the listener's memory, leaving enough time for distant memories and more remote associations to surface. On the other hand, the material stretched beyond the level of intelligibility effectively becomes the background ambience in relation to which we hear other sounds.

The process of stretching audio samples was done in Paul's Extreme Stretch software, which allows soft transitions between sections and a grainy quality of sound, similar to the one obtained in granular synthesis. "I could say it gives the impression of crystal dust scattered so slowly all over a space that it seems frozen in time. This sort of musical material was the starting point for a new understanding and the development of ideas in the evolving music flow of this piece". 4

The ambient noise of the electronics is joined by the string instruments, building the continuous musical lines, "playing mostly semibreves, changing

4 Ibid., 4. 
only the spacing and sometimes the playing technique (sul tasto, sul ponticello, tremolo...)". By extending the electronic noise in this way, the sound of the string corpus builds soft, slowly overlapping walls of the imaginary skyscraper. The building blocks for this layer come diretly from the author's earlier orchestral work The Last Ball of Margarita Nikolayevna: "[I] took a one- minute long sample from the last section [...] - the moment of the harmonic resolving of the chord, I extended the sample by seven times, using the stretching method, and obtained the music layer I needed". ${ }^{5}$

Like looking carefully through a microscope lense, slowing down brings the inner timbral characteristics of the sound to the surface. The simple, transparent vertical, mostly made of minor chords and empty intervals of perfects fourth and perfects fifth, is present throughout the composition. The wealth of harmony is created by combining the impressive soundworld of noises and many different upper harmonics that arise as a consequence of the colour changes i.e. playing techniques.

The music unfolds through several textural layers that may be reduced to the ambient noise of the electronics, accompanied/complemented/imitated by the long held chords in the string instrumental parts and the occasional, various concrete sounds in the electronic part, again accompanied/complemented/imitated in the pointillistically treated wind instruments and percussion. Thus, periodically emulating the sound of the first electronic layer in the orchestra sound that was subsequently composed she combines two different sources into an organic unity. In similar ways, very subtle counterpoints between concrete electronic noises (shattering glass, the voices of children, a creaking door) and motives in the percussion part, or echoes of higher upper harmonics in the strings, musically and imaginatively create rich sounds of objects and echoes.

The short motif with held tones in the woodwind section that is repeated and varied at the ends of phrases throughout the piece (firstly in bars 23-26), then the simple, occasional use of the hi-hat, tympanon, bass drum, and the repetition of isolated concrete sounds in the electronic part, all enhance "the feeling of being frozen in the past". The unchangeable slow tempo and grainy noisy vertical that moves almost unnoticeably, build an object-like form ${ }^{6}$ that

\footnotetext{
5 Ibid., 6.
}

6 According to Ligeti, unlike the standard process forms there are object-like forms, closed in a present moment. "Music as 'frozen' time, as an object in imaginary space evoked by music in our imagination, as a creation which really develops in time, but in 
changes very gradually from one standing position and then going back, thus gently swaying, just like the Pécs skyscraper. "They insist on empty sounding, they give the impression of music standing still in time and in space; and we become aware of the changes that are happening, but not of movement, not of the exact moment when they happen". ${ }^{7}$

Slowing down a phonographic recording of any acoustic performance of a musical composition brings about a change in the function of various musical parametars of the sample. The simultaneity, or the synchronicity of the vertical moments is lost - all the tiny, in real time completely uunnoticable mismatches are amplified many times over. This way the agogical imperfections become the rhythm, completely unpredictable and unrecognisable; what was once irrational is now structural. On the other hand, the rhythm is dissolved and decomposed until its original function is lost in its entirety. The harmonic content translates into melodic content, while the melodies in their endless gradualism become the space. Going behind things does not mean asking questions that are important for the essence of the course as it is, but those questions that have the capacity of changing the perception of what the essence of the course is. ${ }^{8}$ This is one of the effects of the use of the extreme deceleration of recordings as the primary technical and poetic process in a composition.

Just as a lonesome skyscraper, the space of the composition is not humanised, it is not inhabited by subjects. It is inhabited by the sounds of "a child's voice and a woman's laughter, allusions to the non-existant echo of human presence in a once inhabited skyscraper". "The woodwinds are treated pointillistically but with minimal movement, avoiding melodic lines and rhythmical structures. Some latent melodic lines certainly exist, but they are stretched in time". 9 The sound objects in the electronic part are not the bearers of the content. Passive, like stage props, they are placed, spun and varied through the empty, elegiac, noisy space, and then they vanish, leaving noth-

imagination it exists simultaneously in all its moments. According to: Gyoergy Ligeti, Concerto for Piano and Orchestra, Schott Music, text available at: https://en.schott-music. com/shop/konzert-no153614.html, last accessed on 11.09.2019.

7 I. Ognjanović, op. cit., 7

8 According to Ана Гњатовић, Phonation, за глас и електронику: теоријска студија [Ana Gnjatović, Phonation, for voice and electronics: theoretical study], manuscript, Belgrade, 2016.

9 I. Ognjanović, op. cit. 
ing behind. They do not affect the environment in which they exist, they do not change it. The motifs in the orchestra are not embryos, they do not develop into themes, and have no mobilising energy. Depersonalised, they are not singable, or memorable. Different recordings of human voices move through the preverbal, through the inarticulate, through breath or laughter. A quick whisper, quite incomprehensible, is not speach, it does not carry meaning.

Even when human breath is the dominant sound in music, the ever more quickened breathing with which the author builds the dramaturgical growth of the first part of the compostion (from bar 73), is understood as a common (musical) sign, rather than as an individual motif. ${ }^{10}$ Breathing is a very intimate category, and amplified breath is always an effective dramaturgical element. Yet, breathing is also the best known sonic manifestation of the human body, close to everyone, universal, non-individualistic. Also, when recorded from a single position, as in this case, it suggests the stillness of the source i.e. of whoever is breathing. The gradually increasing rate of breathing additionally draws attention to the immobility of the music that becomes the space for internalising what is happening, for the experience rather than the event.

One can conclude that the author (circumstantially, also the listener) builds the closest emotional relationship with the traces of speech in the surroundings, according to the slow, all-pervasive voice of the space. Therefore, Ivana Ognjanović is not intrigued by the lives inside the building, but by the life of the building - by the sad destiny of a place for living in, which is here but is not that. It is a space, standing idly for years without fulfilling its purpose as a victim of "human stupidity and ignorance". When writing about the ending of the composition, full of sympathy, she distinctly sees the building as a person: the string instruments in pianissimo fade upwards in a soft glissando, while echoes of single wind instruments follow them like shadows "the tiny, uncontrolled tremors of a creature already dead". ${ }^{11}$

This way, throughout the composition the author turns music time into space, and the space of a former building into a memory of its unfulfilled role, i.e. - into time. The creaking doors, window panes vibrating and shattering, the elevator moving, even birds flapping their wings, various concrete sounds in the electronic part are all sound sensations that carry the metaphore of

10 Sound example - bars 73-98, the sound of the human breath building the inner tension at the beginning of the second part - are available online at the official New Sound YouTube channel: https://youtu.be/RT1Mr2Buk9Q

11 I. Ognjanović, op. cit., 10. 
transiting from one place to another. "Only the sound of a radio set remains, its dial once left at a station long gone". ${ }^{12}$ Even when she describes the crackling of a radio, Ivana Ognjanović speaks of the resonance of two places that no longer exist.

The Lonesome Skyscraper in Pecs was finally torn down and removed in 2016.

\section{Works cited}

Гњатовић, Ана: Phonation, за глас и електронику: теоријска студија [Ana Gnjatović, Phonation, for voice and electronics: theoretical study], manuscript, Belgrade, 2016.

Ligeti, Gyoergy: Concerto for Piano and Orchestra, (description), Schott Music Online, https://en.schott-music.com/shop/konzert-no153614.html

Ognjanović, Ivana: Lonesome Skyscraper za simfonijski orkestar i elektroniku - prevod elektronskog zvuka u akustični [Lonesome Skyscraper for symphony orchestra and electronics - translation of electronic sound into acoustic], manuscript, Belgrade, October 2012.

\section{Internet sources:}

https://en.wikipedia.org/wiki/High-rise_of_Pécs

https://en.schott-music.com/shop/konzert-no153614.html

12 Ibid. 